\title{
Major Role of Soybean Oil in Preventing Decrease in CYP4A1 mRNA Content Relative to PPAR $\alpha$ mRNA Down-Regulation in Infant Rats
}

\author{
Masuhiro Nishimura, ${ }^{*, a}$ Aiko Yamauchi, ${ }^{b}$ Mari Yamaguchi, ${ }^{a}$ Sanae Kishimoto, ${ }^{a}$ \\ Nobuhiko UedA, ${ }^{a}$ and Shinsaku NAITO ${ }^{a}$ \\ ${ }^{a}$ Division of Pharmacology, Drug Safety and Metabolism, Otsuka Pharmaceutical Factory, Inc.; 115 Tateiwa, Muya-cho, \\ Naruto, Tokushima 772-8601, Japan: and ${ }^{b}$ Department of Pharmaceutical Information Science, Graduate School of \\ Pharmaceutical Science, The University of Tokushima; 1-78 Sho-machi, Tokushima 770-8505, Japan. \\ Received April 5, 2005; accepted May 27, 2005; published online May 31, 2005
}

Changes in the levels of CYP4A1, PPAR $\alpha$, and RXR $\alpha$ mRNA expression in the liver following overdose of fat-free or fat-containing total parenteral nutrition (TPN) were studied in 3-week-old male Sprague-Dawley rats. The rats were divided into three groups: group 1, oral diet; group 2, fat-free TPN; and group 3, TPN with $20 \%$ of calories from soybean oil emulsion. Levels of CYP4A1, PPAR $\alpha$, and RXR $\alpha$ mRNA in the fat-free TPN group were significantly lower than those in the other groups. Levels of CYP4A1 and PPAR $\alpha$ mRNA were strongly correlated $(r=0.849)$, and levels of CYP4A1 and $R X R \alpha$ mRNA were weakly correlated $(r=0.618)$. This is the first report of a strong correlation between the levels of CYP4A1 and PPAR $\alpha$ mRNA following overdose of fat-free or fat-containing TPN in infant rats. Our results also indicate that it is important to include fat in TPN regimens in order to prevent CYP4A1 mRNA down-regulation, which may be related to changes in PPAR $\alpha$ mRNA levels in the liver.

Key words fat; CYP4A1; peroxisome proliferators-activated receptor- $\alpha$; infant rat liver; total parenteral nutrition; soybean oil emulsion

Total parenteral nutrition (TPN), which is also known as parenteral hyperalimentation, provides complete nutritional therapy by the infusion of nutrients directly into the systemic circulation. It is thought that hepatic dysfunction with steatosis is the most common complication associated with fat-free TPN, but in infants, it is said to express itself as cholestasis. ${ }^{1,2}$ We have recently developed an infant rat model of hepatic dysfunction and steatosis induced by overdose of fatfree TPN. ${ }^{3)}$ In a recent study, it was clearly demonstrated that the infusion of excessive glucose resulted in increased hepatic lipogenesis ${ }^{4}$ and decreased lipolysis (unpublished observations) and that including fat in the TPN regimen is very important in preventing hepatic dysfunction and cholestasis. ${ }^{4)}$ The efficacy of 3-component infusion solutions has also been demonstrated using a TPN solution containing amino acids, glucose, and soybean oil emulsion in clinical studies. ${ }^{5)}$

The CYP4As are fatty acid and prostaglandin hydroxylases that are abundantly expressed in the liver and kidney. ${ }^{6,7)}$ These enzymes can hydroxylate saturated and unsaturated fatty acids at the $\omega$ and $\omega-1$ positions, with a clear preference for the $\omega$ position. ${ }^{8)}$ The peroxisome proliferators-activated receptor- $\alpha(\operatorname{PPAR} \alpha)$ is a member of the nuclear hormone receptor superfamily, which requires another dimerization partner, the retinoid $\mathrm{X}$ receptor $(\mathrm{RXR} \alpha)$, for gene activation. ${ }^{9)}$ It has been suggested that PPAR $\alpha$ and RXR $\alpha$ play important roles in hepatic CYP4A1 regulation. ${ }^{10)}$ We have reported that the infusion of excessive glucose results in the down-regulation of hepatic cytochrome P450 mRNA and that including fat in the TPN regimen is very important in preventing this effect. ${ }^{11)}$ However, no reports describing in detail the relationships between the changes in CYP4A1 and nuclear receptors such as PPAR $\alpha$ and $\mathrm{RXR} \alpha$ during TPN treatment have appeared in the literature.

The present animal study therefore focused on clarifying the changes in the mRNA expression of CYP4A1 in this infant rat model following the administration of TPN with or without fat (soybean oil emulsion) for $4 \mathrm{~d}$. The relationships between CYP4A1 and nuclear receptors such as PPAR $\alpha$ and $\mathrm{RXR} \alpha$ with regard to mRNA expression were also assessed.

\section{MATERIALS AND METHODS}

Animals and Diets Male Sprague-Dawley rats at 3 weeks of age were obtained from Charles River Japan SLC, Inc. (Kanagawa, Japan). The rats were housed in a room with a 12-h light: dark schedule and allowed free access to water and standard rat diet containing $54.5 \mathrm{starch}, 22.4$ protein, 5.7 fat, 3.1 fiber, and 6.6 mineral and vitamin mixture (all values given as g/100 g; CRF-1, Oriental Yeast Co., Ltd., Tokyo, Japan).

Materials The Rneasy ${ }^{\circledR}$ Mini kit and QIAshredder ${ }^{\mathrm{TM}}$ were purchased from QIAGEN (Hilden, Germany). Yeast tRNA was purchased from Life Technologies, Inc. (Rockville, MD, U.S.A.). The TaqMan One-Step RT-PCR Master Mix reagents kit was purchased from Applied Biosystems (Foster City, CA, U.S.A.). All other chemicals and reagents used were of analytical reagent grade.

Surgery, Infusion of Parenteral Nutrition, and Sample Collection The present study was approved by the Committee on the Care and Use of Laboratory Animals of Otsuka Pharmaceutical Factory, Inc.

Surgery and infusion of TPN were performed according to the method of Oshita et al. ${ }^{3)}$ Briefly, infant (3-week-old) male Sprague-Dawley rats weighing $60-70 \mathrm{~g}$ were randomly allocated to three groups ( $n=8$ in each group) in this study: group 1 received an oral diet, group 2 received TPN without fat, and group 3 received TPN with $20 \%$ of calories from fat (soybean oil emulsion). In this report, group 1 is referred to as the oral diet group, and groups 2 and 3 are collectively referred to as the TPN groups. In the TPN groups, after the rats were fasted overnight, a catheter for the infusion of parenteral nutrition was placed in the jugular vein under general 
Table 1. Compositions of Fat-Free and Fat-Containing Total Parenteral Nutrition (TPN) Solutions (Fat Provided in the Form of Soybean Oil Emulsion)

\begin{tabular}{lccc}
\hline \hline & Unit & Fat-free TPN & Fat-containing $\mathrm{TPN}^{a)}$ \\
\hline Volume & $(\mathrm{ml})$ & 900 & 900 \\
Glucose & $(\mathrm{g})$ & $194.6(778 \mathrm{kcal})$ & $150(600 \mathrm{kcal})$ \\
Soybean oil emulsion & $(\mathrm{g})$ & $0(0 \mathrm{kcal})$ & $19.8(178 \mathrm{kcal})$ \\
Amino acids & $(\mathrm{g})$ & $30(120 \mathrm{kcal})$ & $30(120 \mathrm{kcal})$ \\
$\mathrm{Na}$ & $(\mathrm{mEq})$ & 34.6 & 35 \\
$\mathrm{~K}$ & $(\mathrm{mEq})$ & 27 & 27 \\
$\mathrm{Mg}$ & $(\mathrm{mEq})$ & 5 & 5 \\
$\mathrm{Ca}$ & $(\mathrm{mEq})$ & 8.5 & 8.5 \\
$\mathrm{Cl}$ & $(\mathrm{mEq})$ & 46 & 40.5 \\
$\mathrm{Acetate}$ & $(\mathrm{mEq})$ & 47 & 25 \\
$\mathrm{Gluconate}$ & $(\mathrm{mEq})$ & 8.4 & 8.5 \\
$\mathrm{P}$ & $(\mathrm{mg})$ & 125 & 200 \\
Zn & $(\mu \mathrm{mol})$ & 10 & 10 \\
\hline
\end{tabular}

a) $\operatorname{MIXID}^{\circledR}(\mathrm{GA}-1080)$ formulation. ${ }^{5)}$

anesthesia with diethyl ether. All TPN regimens were isocaloric $(1000 \mathrm{kcal} / \mathrm{l})$ and isonitrogenic. The compositions of the TPN solutions with and without fat are shown in Table 1. The TPN solution with fat was MIXID ${ }^{\circledR}$ formulation (GA1080, Otsuka Pharmaceutical Co., Ltd., Tokyo, Japan). ${ }^{5}$ Otsuka MV injection (Otsuka Pharmaceutical Co., Ltd.) was used to supply vitamins. Infusion was started immediately after cannulation at $3 \mathrm{ml} / \mathrm{kg}$ body weight $/ \mathrm{h}$ for the first $12 \mathrm{~h}$ and then increased in a stepwise manner every $12 \mathrm{~h}$ to 10,20 , and then $30 \mathrm{ml} / \mathrm{kg} / \mathrm{h}$. On the third day, the infusion rate was increased to $40 \mathrm{ml} / \mathrm{kg} / \mathrm{h}$ (i.e., full-dose TPN) and maintained at that level thereafter. The total experimental period was $4 \mathrm{~d}$, and continuous infusion was maintained with a Terufusion pump (Terumo Co., Tokyo, Japan). An administration rate of $40 \mathrm{ml} / \mathrm{kg} / \mathrm{h}$, which was found to induce abnormal changes in blood chemistry values suggestive of cholestasis and hepatic dysfunction in the dose selection study, was used in the present study. The animals were anesthetized with diethyl ether and the abdominal cavity was opened. Blood samples were drawn from the vena cava and the animals were killed by exsanguination, after which the entire liver was rapidly excised. The blood samples were placed in tubes with or without EDTA- $\mathrm{Na}_{2}$ and were immediately centrifuged. Total RNA was extracted from the liver using the Rneasy ${ }^{\circledR}$ Mini kit and QIAshredder ${ }^{\mathrm{TM}}$.

Biochemical Examination Serum samples were analyzed for aspartate aminotransferase (AST) and alanine aminotransferase (ALT) using an autoanalyzer (Model 7170, Hitachi Co., Tokyo, Japan). AST and ALT activities were measured by the JSCC (Japan Society of Clinical Chemistry) transferable method.

Oligonucleotides The forward and reverse primers and the TaqMan probes were designed using Primer Express software (Applied Biosystems) from the rat mRNA sequence (Table 2). Each primer and/or probe was homology searched by an NCBI BLAST search to ensure that it was specific for the target mRNA transcript. The primers and TaqMan probes were synthesized by QIAGEN (Tokyo, Japan). The TaqMan probes contained 6-carboxyfluorescein (FAM) at the $5^{\prime}$ end and 6-carboxytetramethylrhodamine (TAMRA) at the $3^{\prime}$ end and were designed to hybridize to a sequence located between the PCR primers.

TaqMan RT-PCR Conditions Total hepatic RNA was

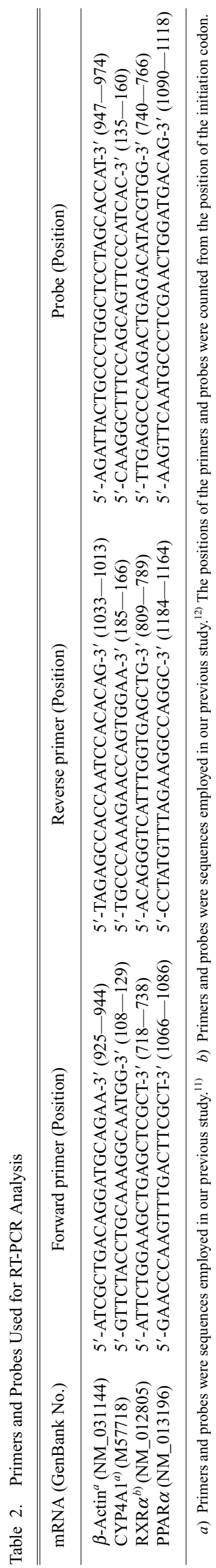


diluted with $50-\mu \mathrm{g} / \mathrm{ml}$ yeast tRNA to $5 \mu \mathrm{g} / \mathrm{ml}$. The RT-PCR assay was performed using the ABI PRISM 7700 Sequence Detector system (Applied Biosystems) under the same conditions as in our previous studies. ${ }^{11,12)}$ The relative expression of each mRNA was calculated by the $\Delta \mathrm{Ct}$ method (where $\Delta \mathrm{Ct}$ is the value obtained by subtracting the $\mathrm{Ct}$ value of $\beta$ actin mRNA from the $\mathrm{Ct}$ value of the target mRNA), as employed in previous studies. ${ }^{11-14)}$ Specifically, the amount of target mRNA relative to $\beta$-actin mRNA is expressed as $2^{-(\Delta \mathrm{Ct})}$. Data are expressed as the ratio of target mRNA to $\beta$ actin mRNA.

Statistical Analysis Studies were conducted in duplicate and data are shown as mean \pm S.D. of 8 rats. The statistical significance of differences between mean values was analyzed by the Tukey's test.

\section{RESULTS}

Adverse Effects and Biochemical Findings None of the animals in the fat-free or fat-containing TPN groups showed any adverse effects such as debilitation or reduced mobility following the surgical procedure, as assessed by gross examination, during the period of TPN administration. In the fatfree TPN group, both the serum AST and ALT levels were significantly higher $(p<0.001)$ than those in the other groups (oral diet and fat-containing TPN), whereas there were no significant differences between the other groups in either serum AST or ALT levels (Table 3).

Changes in CYP4A1, PPAR $\alpha$, and RXR $\alpha$ mRNA Expression The level of CYP4A1 mRNA in the fat-free TPN group was significantly lower $(p<0.01$ and $p<0.05$, respectively) than the levels in both the oral diet and fat-containing TPN groups (Fig. 1). The level of PPAR $\alpha$ mRNA in the fatfree TPN group was significantly lower $(p<0.01)$ than that in the other groups (Fig. 1). The level of RXR $\alpha$ mRNA in the fat-free TPN group was also significantly lower $(p<0.001)$ than that in the other groups (Fig. 1). The mRNA levels of CYP4A1 and PPAR $\alpha$ were strongly correlated $(r=0.849)$, and the mRNA levels of CYP4A1 and $\operatorname{RXR} \alpha$ were weakly correlated ( $r=0.618)$ (Fig. 2).

\section{DISCUSSION}

We have previously reported that the infusion of excessive glucose results in the down-regulation of hepatic cytochrome P450 mRNA, and that including fat in the TPN regimen is very important in preventing this effect. ${ }^{11)}$ Furthermore, $\operatorname{PPAR} \alpha$ and $\operatorname{RXR} \alpha$ play important roles in hepatic CYP down-regulation by endotoxin. ${ }^{10}$ Therefore, in the present study, we focused on the changes in hepatic CYP4A1 mRNA levels in infant rats. Furthermore, we evaluated the changes in the levels of hepatic PPAR $\alpha$ and $\operatorname{RXR} \alpha$ mRNA in infant rats. The results of the present study indicate that the changes in PPAR $\alpha$ mRNA levels associated with overdose of fat-free or fat-containing TPN in infant rats may be one factor responsible for the regulation of the level of CYP4A1 mRNA expression and that the changes in the levels of $\operatorname{RXR} \alpha$ mRNA probably play only a small role in the regulation of CYP4A1 mRNA expression. Furthermore, the results of the present study indicate the great importance of including fat in the TPN regimen in order to prevent CYP4A1 mRNA
Table 3. Biochemical Examination (Serum AST and ALT) in Infant Rats That Received TPN for $4 \mathrm{~d}$

\begin{tabular}{cccc}
\hline \hline & $\begin{array}{c}\text { Group 1 } \\
\text { Oral diet }\end{array}$ & $\begin{array}{c}\text { Group 2 } \\
\text { Fat-free TPN }\end{array}$ & $\begin{array}{c}\text { Group 3 } \\
\text { Fat-containing TPN }\end{array}$ \\
\hline AST (U/1) & $92 \pm 7$ & $1661 \pm 578 * * *$ & $116 \pm 38^{\text {市 }}$ \\
ALT (U/1) & $39 \pm 5$ & $284 \pm 90 * * *$ & $33 \pm 10^{\dagger \dagger \dagger}$ \\
\hline
\end{tabular}

Data are shown as mean \pm S.D. $(n=8)$. The statistical significance of differences between values was analyzed by the Tukey's test. Significant difference at $* * * p<0.001$ $v s$. group 1 , $\dagger^{\dagger \dagger} p<0.001 v s$. group 2 .

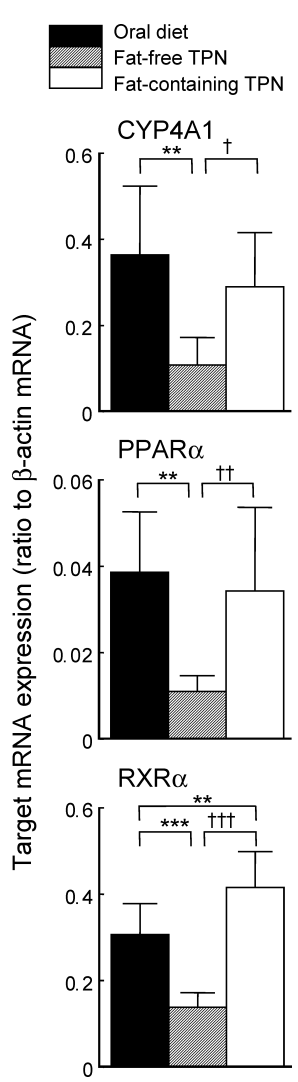

Fig. 1. Changes in CYP4A1, PPAR $\alpha$, and $\mathrm{RXR} \alpha$ mRNA Expression in Infant Rats That Received TPN for $4 \mathrm{~d}$

Data are expressed as the ratio of the target mRNA to $\beta$-actin mRNA. Values are mean \pm S.D. $(n=8)$. The statistical significance of differences between values was analyzed by the Tukey's test. Significant difference at $* * p<0.01$ and $* * * p<0.001 v s$. oral diet group, ${ }^{\dagger} p<0.05$, ${ }^{\dagger} p<0.01$, and ${ }^{\dagger \dagger} p<0.001 v s$. fat-free TPN group.
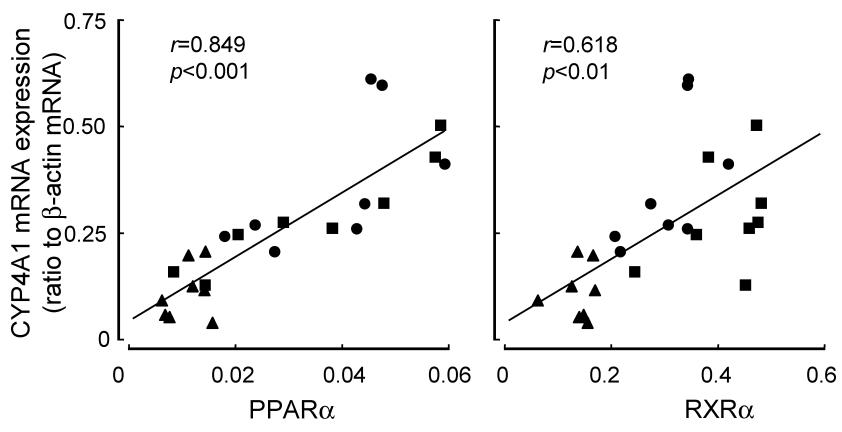

Target mRNA expression (ratio to $\beta$-actin mRNA)

Fig. 2. Relationships between mRNA Levels of CYP4A1 and Nuclear Receptors Such as PPAR $\alpha$ and $\operatorname{RXR} \alpha$ in Infant Rats That Received TPN for $4 \mathrm{~d}$

Oral diet group: closed circles $(\bullet, n=8)$, fat-free TPN group: closed triangles $(\boldsymbol{\Lambda}$, $n=8)$, and fat-containing TPN group: closed squares $(\boldsymbol{\square}, n=8)$. 
down-regulation, which may be related to the changes in $\operatorname{PPAR} \alpha$ mRNA levels in the liver of the infant rat.

It was also demonstrated that fatty acids are ligands for PPAR $\alpha$, providing strong evidence that they are endogenous PPAR $\alpha$ activators. ${ }^{15,16)}$ Therefore, it appears that when a fatfree TPN regimen is used, the activation of PPAR $\alpha$ as well as CYP4A1 mRNA down-regulation via the activation of PPAR $\alpha$ may not occur. Furthermore, the prevention of CYP4A1 mRNA down-regulation may be due to the activation of PPAR $\alpha$ by fatty acids contained in the TPN solution.

In conclusion, the present study is the first to report that the mRNA levels of CYP4A1 are strongly correlated those of PPAR $\alpha$ following overdose of fat-free or fat-containing TPN in infant rats. Further research is needed to elucidate the precise mechanism by which the down-regulation of hepatic CYP4A1 mRNA expression following fat-free TPN is associated with changes in PPAR $\alpha$ mRNA expression.

Acknowledgments The authors would like to thank David G. Spear, M.D., for reviewing the manuscript.

\section{REFERENCES}

1) Bernstein J., Chang C. H., Brough A. J., Heidelberger K. P., J. Pediatr. 90, 361-367 (1977)

2) Benjamin D. R., Am. J. Clin. Pathol., 76, 276-283 (1981).
3) Oshita M., Takehara H., Yamaguchi M., Doi K., Ueda N., Naito S., Hiraoka I., Tashiro S., Clin. Nutr., 23, 1060-1068 (2004).

4) Yamaguchi M., Doi K., Nishimura M., Doi M., Kishimoto S., Koshitani O., Ichikawa S., Shinohara S., Ueda N., Naito S., Hiraoka I., Oshita M., Takehara H., J. JSPEN, 19, 71-79 (2004) (in Japanese).

5) Saitoh Y., Oyanagi H., Nippon Rinsho, 59 (Suppl. 5), 906-909 (2001) (in Japanese).

6) Simpson A. E., Gen. Pharmacol., 28, 351-359 (1997).

7) Nishimura M., Yaguti H., Yoshitsugu H., Naito S., Satoh T., Yakugaku Zasshi, 123, 369-375 (2003).

8) Aoyama T., Hardwick J. P., Imaoka S., Funae Y., Gelboin H. V., Gonzalez F. J., J. Lipid Res., 31, 1477-1482 (1990).

9) Issemann I., Prince R. A., Tugwood J. D., Green S., J. Mol. Endocrinol., 11, 37-47 (1993).

10) Johnson E. F., Hsu M. H., Savas U., Griffin K. J., Toxicology, 181182, 203-206 (2002).

11) Yamaguchi M., Yamauchi A., Nishimura M., Ueda N., Naito S., Biol. Pharm. Bull., 28, 143-147 (2005).

12) Nishimura M., Yamaguchi M., Yamauchi A., Ueda N., Naito S., Drug Metab. Pharmacokinet., 20, 46-54 (2005).

13) Nishimura M., Naito S., Yokoi T., Drug Metab. Pharmacokinet., 19, 135-149 (2004)

14) Nishimura M., Imai T., Morioka Y., Kuribayashi S., Kamataki T., Naito S., Drug Metab. Pharmacokinet., 19, 422-429 (2004).

15) Kliewer S. A., Sundseth S. S., Jones S. A., Brown P. J., Wisely G. B., Koble C. S., Devchand P., Wahli W., Willson T. M., Lenhard J. M., Lehmann J. M., Proc. Natl. Acad. Sci. U.S.A., 94, 4318-4323 (1997).

16) Forman B. M., Chen J., Evans R. M., Proc. Natl. Acad. Sci. U.S.A., 94, $4312-4317$ (1997). 